\title{
Feeding behavior, microbial efficiency, and nitrogen balance of Nellore heifers supplemented with crude glycerin
}

\author{
Comportamento ingestivo, síntese microbiana e balanço de \\ nitrogênio de novilhas Nelore suplementadas com glicerina bruta
}

\author{
Gonçalo Mesquita da Silva ${ }^{1 *}$; Fabiano Ferreira da Silva²; Robério Rodrigues Silva²; \\ Fábio Andrade Texeira²; Dicastro Dias de Souza ${ }^{1}$; Murilo de Almeida Meneses ${ }^{1}$; \\ Antonio Ferraz Porto Junior ${ }^{1}$; Leidiane Reis Pimentel ${ }^{1}$; \\ Eli Santana de Oliveira Rodrigues ${ }^{1}$; Pablo Teixeira Viana ${ }^{1}$
}

\begin{abstract}
This study aimed to evaluate the inclusion of crude glycerin in diets for Nellore heifers grazing on a Brachiaria brizantha pasture, during the dry season, on urine and plasma urea concentrations, feeding behavior, and microbial protein synthesis. Sixty Nellore heifers with an average initial weight of 285.89 $\pm 18.74 \mathrm{~kg}$, at approximately $19 \pm 2$ months of age, were distributed, in a completely randomized design, into the following five treatments with twelve replicates: $0.00,4.00,8.00,12.00$, and $16.00 \%$ inclusion of crude glycerin in the diet they were fed. Grazing time decreased linearly $(\mathrm{P}<0.05)$ by 7.44 min with every percent of crude glycerin included in the diet. Microbial efficiency was not affected ( $\mathrm{P}>0.05$ ), averaging $113.73 \mathrm{~g} \mathrm{CP}$ per $\mathrm{kg}$ TDN ingested. Plasma nitrogen concentration did not show any effects ( $\mathrm{P}>0.05)$, averaging $13.11 \mathrm{mg} \mathrm{dL}^{-1}$. Supplementing heifers during the dry season, at $0.7 \% \mathrm{BW}$, using up to $16 \%$ crude glycerin in the diet composition, did not elicit positive responses from feeding behavior and had little influence on microbial synthesis.
\end{abstract}

Key words: Efficiency. Glycerol. Grazing. Rumination.

\section{Resumo}

Objetivou-se avaliar a inclusão de glicerina bruta na dieta de novilhas Nelore em pastejo de Brachiaria brizantha no período da seca, sobre as concentrações de ureia na urina e no plasma, o comportamento ingestivo e a sínteses de proteína microbiana. Foram utilizadas 60 novilhas da raça Nelore, com peso médio inicial $285,89 \pm 18,74 \mathrm{~kg}$ e aproximadamente $19 \pm 2$ meses de idade, distribuídas em um delineamento inteiramente casualizado, sobre 5 tratamentos e 12 repetições: 0,$00 ; 4,00 ; 8,00 ; 12,00$ e $16,00 \%$ de inclusão de glicerina bruta na dieta das novilhas. O tempo de pastejo apresentou efeito linear decrescente $(\mathrm{P}<0,05)$, para cada porcentagem de glicerina bruta inclusa na dieta, foi observada uma redução de 7,44 minutos. A eficiência microbiana não apresentou efeito $(\mathrm{P}>0,05)$, com valor médio de $113,73 \mathrm{~g}$ de PB por kg de NDT ingerido. A concentração de nitrogênio no plasma não apresentou efeito ( $\mathrm{P}>0,05)$, tendo assim, valor médio de $13,11 \mathrm{mg} \mathrm{dl}^{-1}$. A suplementação de novilhas no período seco com $0,7 \%$ PC com utilização da glicerina bruta na composição da dieta até $16,00 \%$ não proporcionou

\footnotetext{
${ }^{1}$ Discentes do Curso de Doutorado do Programa de Pós-Graduação em Zootecnia, Universidade Estadual do Sudoeste da Bahia, UESB, Itapetinga, BA. E-mail: gon_zootecnia23@hotmail.com; dico111_3@hotmail.com; dddmeneses@msn.com; ferrazporto@hotmail.com; leidyrp@yahoo.com.br; eli.uesb@hotmail.com; pabloviana83@gmail.com

2 Pesquisadores, Universidade Estadual do Sudoeste da Bahia, UESB, Itapetinga, BA. E-mail: ffsilvauesb@hotmail.com; rrsilva. uesb@hotmail.com; fteixeira@uesb.edu.br

* Autor for correspondence
} 
respostas positivas para o comportamento ingestivo e apresentou pouca influência sobre a síntese microbiana.

Palavras-chave: Eficiência. Glicerol. Pastejo. Ruminação.

\section{Introduction}

The beef cattle production system in Brazil is basically carried out with animals grazing on grasses of the genera Brachiaria and Panicum, besides other forage varieties, as is the case of some legume species and native vegetation sought for animal production, which are feed sources for cattle distributed across the regions of the country.

In the dry period of the year, during which rainfall scarcity is present from May to October in a great part of the regions of Brazil, these forages have their production and qualitative potential reduced. This requires the use of supplementation with protein and energy concentrates to maintain animals alive and under production, aiming to lessen the negative effects on the livestock activity.

In the Brazilian cattle farming activity, the use of tropical pastures and supplementation, especially during the dry season, has been exploited so as to make beef cattle rearing systems biologically feasible, as stated by Silva et al. (2009).

According to Silva et al. (2010), the limiting factor in forage intake by grazing animals is related to three groups of specific factors: those affecting the digestion processes, the ingestion processes, and the nutritional requirements. The feeding behavior of cattle on pasture is influenced by both the quantity and the quality of the dry matter produced, generating a positive or negative effect on animal productivity.

However, other also related factors non-inherent to the vegetation, but directly linked to the feeding behavior, such as the use of supplementation, may provide changes in the behavior displayed by animals, as reported by Souza et al. (2011).

Depending on the quantity of the supplement provided to animals, their dry matter (DM) intake from the pasture can be reduced or increased, thereby causing a substitution effect on forage intake via the consumption of concentrate, and in smaller quantities of supplement, an additive effect on pasture intake.

The feeding behavior of grazing cattle is characterized by long feeding periods, from 4 to $12 \mathrm{~h}$ day $^{-1}$, for low-energy diets. The time spent grazing and ruminating is influenced by the pasture and by the use of supplements (MARTINS et al., 2012).

Supplementing cattle on a grazing system in the dry season is a practice aimed at maximizing the productive performance of animals. As a strategy in decision-making, producers have sought to insert alternative feedstuffs in animal diets partially or totally replacing traditional ingredients (maize, soybean, and wheat), aiming to reduce effective operating costs (EOC).

Waste from biodiesel industries has been utilized in the composition of ruminant diets aiming to meet the nutritional requirements of grazing animals. Among them, the crude glycerin has stood out as an alternative feedstuff to supplement cattle on grazing systems, especially during the dry season.

Crude glycerin is a by-product from the biodiesel industry obtained from the transesterification reaction for the formation of biodiesel. Its composition contains impurities like water, catalyst (alkaline or acid), non-reacted alcohol, and impurities originating from ester reagents, propanediols, monoesters, glycerin oligomers, and polymers (FERRARI et al., 2005). Being devoid of protein in its composition, crude glycerin in large quantities can influence the growth of rumen microorganisms and promote their activity on the fiber degradation. 
Ruminants have the ability to utilize the glycerol present in crude glycerin as a precursor of glycogen, for the maintenance of plasma glucose levels. Glycerol is converted to glucose, which enters in dihydroxyacetone phosphate form to be converted to 3-phosphoglycerate by the action of the glycerol3-phosphate dehydrogenase enzyme following the gluconeogenic pathway (FARIAS et al., 2012).

Given the importance of the nitrogen balance and the microbial synthesis on the protein metabolism of ruminants, it is important to know the metabolic variations in the urine, feces, and blood, as well as the efficiency of microbial protein production promoted by changes in the animal diets (SCHIO, 2012), mainly when alternative feedstuffs are added to these diets.

This study aimed to test levels of crude glycerin in diets for Nellore heifers grazing on Brachiaria brizantha pastures during the dry season and their implications on the feeding behavior, microbial synthesis, and nitrogen balance of these animals.

\section{Materials and Methods}

The experiment was conducted on Boa Vista Farm, in Macarani-BA, Brazil, for the field part and data collection; and at the Laboratory of Forage Crops and Pasture of the Southwest Bahia State University (UESB) - Juvino Oliveira campus, in
Itapetinga-BA, for chemical analyses of forage, supplements, and feces.

Sixty Nellore heifers at an average age of $19 \pm 2$ months and with $285.89 \pm 18.74 \mathrm{~kg}$ initial body weight were used in a randomized complete design, where they were distributed into five treatments and twelve replications. After selection, all animals were allotted at random to the established treatments with $0.00,4.00,8.00$, 12.00 , and $16.00 \%$ inclusion of crude glycerin in the heifer diets.

The experiment started on July 15, 2011 and lasted 85 days, which consisted of 15 days for the adaptation of animals to diets and paddocks, and the remaining 70 days for data collection and evaluation of performance, divided into two 35-day experimental periods.

Climatic data referring to the experimental period were obtained using a pluviometer and a digital thermometer. Total precipitation values $(51 \mathrm{~mm}$ day $^{-1}$ ) and minimum and maximum temperatures $\left(18.85\right.$ and $31.13{ }^{\circ} \mathrm{C}$ ) were recorded during the experiment.

Supplements were formulated using the chemical composition data of the forage samples, collected in the week prior to the beginning of the experimental period (Table 1), to provide nutrients to animals with an estimated gain of $0.750 \mathrm{~kg} \mathrm{day}^{-1}$, according to NRC (1996).

Table1. Proportion of ingredients in the supplement and chemical composition, on a dry matter basis.

\begin{tabular}{lccccc}
\hline \multirow{2}{*}{ Ingredient } & \multicolumn{5}{c}{ Crude glycerin level (\%) } \\
\cline { 2 - 6 } & $\mathbf{0 . 0 0}$ & $\mathbf{4 . 0 0}$ & $\mathbf{8 . 0 0}$ & $\mathbf{1 2 . 0 0}$ & $\mathbf{1 6 . 0 0}$ \\
\hline Ground maize & 80.86 & 67.91 & 54.62 & 41 & 27.04 \\
Glycerin & 0.00 & 10.47 & 21.2 & 32.20 & 43.49 \\
Soybean meal & 15.30 & 17.74 & 20.25 & 22.81 & 25.44 \\
Post-weaning salt $^{1}$ & 1.85 & 1.87 & 1.89 & 1.92 & 1.94 \\
Urea & 1.99 & 2.01 & 2.04 & 2.07 & 2.09 \\
\hline
\end{tabular}

${ }^{1}$ Mineralmixcontaining: 233 g Ca/kg; 80 g P/kg; 5 g Mg/kg; 48 g Na/kg; 25 mg Co/kg; 380 mg Cu/kg; 25 mg I/kg; 1,080 mg Mn/ $\mathrm{kg} ; 3.75 \mathrm{mg} \mathrm{Se} / \mathrm{kg} ; 1,722 \mathrm{mg} \mathrm{Zn/kg}$. 
To regulate the feed supply to heifers, the animals were weighed at the beginning and in the middle of the experiment. Supplements were supplied daily in the amount of $0.7 \%$ body weight (BW) at $08 \mathrm{~h} 30$, in a collective 4-m-long plastic trough with double access, located $15 \mathrm{~m}$ from the water source. All animals had free access to natural shade provided by trees in the pasture between the paddocks, fresh drinking water, and a high-intake supplement during the entire experimental period.

The experiment was established in a 30-ha area formed by Brachiaria brizantha cultivar Marandu, divided into 10 paddocks with approximately 3 ha each. The experimental area was closed, surrounded by electric fences, three months before the start of the experiment. The pasture was deferred aiming to increase the green herbage mass existing in the paddocks, which served to calculate the allowance and availability of pasture dry matter to the animals during the experimental period.

During the first experimental period, heifers were rotated across five paddocks in a direction predefined at random for minimizing effects inherent to the paddocks. Meanwhile, five paddocks remained closed to be used in the second experimental period; these were rotated by the heifers in a direction predefined at random for minimizing effects inherent to the paddocks until the end of the experiment.

To determine the qualitative and quantitative characteristics of the Brachiaria brizantha, initial, intermediate, and final forage sample collections were carried out during the experimental period. Initially, the dry matter (DM) of the biomass of the sample in the entire experimental area was quantified visually before the animals were placed in the paddock, in order to quantify the existing scores, considering the height as a parameter. Forage with 20 to $30 \mathrm{~cm}$ in height was defined as score 1; between 30 and $40 \mathrm{~cm}$, score 2; and from 40 to 50 , score 3 .
In the same way, after the paddocks were divided, the same methodology described above was employed to visually quantify the biomass of the pasture sample and the existing scores; these assessments were made in the periods the animals entered and exited the paddocks, determined using a $0.25-\mathrm{m}^{2}$ square frame and scissors. The frame was thrown over each paddock 40 times and values from the score on which the frame fell were recorded in proper spreadsheets.

After this procedure, four forage collections were performed $5 \mathrm{~cm}$ above the soil level. The material was placed in plastic bags and weighed; values were recorded, and a composite sample was made from which the components were separated into leaf, stem, and dead material.

Stocking rate was calculated considering the animal unit (AU) as $450 \mathrm{~kg}$ of live weight (BW), as shown in Eq. 1:

$$
\text { Eq. } 1=\mathrm{SR}=\frac{(\mathrm{tAU})}{\text { Area }}
$$

where $\mathrm{SR}=$ stocking rate, in $\mathrm{AU}$ per ha; tAU = total animal unity; and Area = total experimental area, in ha.

Forage allowance was calculated according to Eq. 2:

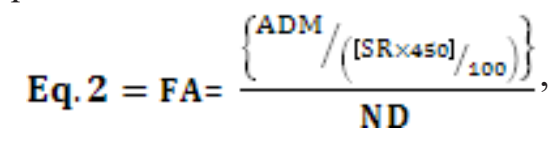

where FA is the forage allowance in $\mathrm{kg}$ DM 100 $\mathrm{kgBW}^{-1}$ day $^{-1}$; available dry matter (ADM)is the pasture dry matter availability, in $\mathrm{kg} \mathrm{DMha}^{-1}$ day $^{-1}$; $\mathrm{SR}$ is the stocking rate, in $\mathrm{AU} \mathrm{ha}{ }^{-1}$; and number of days per hectare (ND)is the number of days in the experimental period.

From the pasture sample collection procedures, during the entire experimental period, we obtained the mean values for forage DM availability of the respective Brachiaria brizantha components, stocking rate, and forage allowance, as presented in Table 2 . 
Table 2.Forage production in experimental paddocks.

\begin{tabular}{|c|c|}
\hline Forage production & Paddocks average \\
\hline Available dry matter $\left(\mathrm{kg} \mathrm{ha}^{-1}\right)$ & $9,056.15$ \\
\hline Percentage of leaf $(\% \mathrm{DM})$ & 27.52 \\
\hline Percentage of stem (\% DM) & 38.46 \\
\hline Percentage of dead material (\% DM) & 34.02 \\
\hline Stocking rate $\left(\mathrm{AU}_{\mathrm{ha}}{ }^{-1}\right)$ & 2.37 \\
\hline Forage allowance (kg DM $100 \mathrm{~kg} \mathrm{BW}^{-1}$ ) & 12.83 \\
\hline
\end{tabular}

Pasture collection was achieved by the handplucking (simulated grazing) technique, by collecting the pasture from the consumed stratum, simulating the real composition of the animal's roughage diet. The individual dry weight and percentage of each one of these samples were obtained.

Purified and enriched lignin (LIPE) was used for the estimate of fecal production, according to the methodology utilized by Rodriguez et al. (2006). LIPE was supplied daily at $08 \mathrm{~h} 30$ as an external marker, in a single dose in a 500-mg capsule, for seven days. Two of these days were intended for adaptation and regulation of the marker excretion flow, and the other five for feces collection.

Approximately $200 \mathrm{~g}$ of feces animal ${ }^{-1} \mathrm{day}^{-1}$ were collected directly from the rectal ampulla, once daily, for five days, when the marker was administered. Subsequently, they were stored in a freezer at $-10^{\circ} \mathrm{C}$. LIPE was analyzed at the Animal Nutritional Laboratory of EV/UFMG, on a Varian 099-2243 spectrophotometer with an infrared light detector (FTIR). Samples of feces dried and ground to $2 \mathrm{~mm}$ were $\mathrm{KBr}$-pelleted, and the LIPE concentration was determined.

Dry matter intake from the concentrate was estimated using the titanium dioxide marker, according to the methodology utilized by Titgemeyer
(1997). Ten grams of the marker were used per animal per day, directly in the trough, mixed with the concentrate, for 12 consecutive days, following the procedure described by Rodriguez et al. (2006). The first seven days were used for adaptation and regulation of the marker excretion flow, and the other five for feces collections. This procedure applied for the digestibility of nutrients took place in the middle of the experimental period. When animals were already acclimated to the diet, all of them had their feces collected.

Samples of the supplements provided in the beginning and at the end of the experimental periods were collected. Hand-plucked, supplements, and feces samples were dried in a forced-air oven at 55 ${ }^{\circ} \mathrm{C}$ for $72 \mathrm{~h}$ and processed in a Wiley mill with $1-\mathrm{mm}$ sieve. Later, the samples were analyzed chemically to determine the dry matter (OM), organic matter $(\mathrm{OM})$, crude protein $(\mathrm{CP})$, ether extract (EE), neutral detergent fiber (NDF), acid detergent fiber (ADF), hemicellulose, cellulose, lignin, and mineral matter (MM) contents, as shown in Table 3 , according to procedures described by Silva and Queiroz (2002).

Concentrations of neutral detergent fiber corrected for ash and protein were determined following recommendations of Mertens (2002). 
Table 3. Chemical composition of the diet.

\begin{tabular}{lccccccc}
\hline \multirow{2}{*}{ Component } & \multirow{2}{*}{$\mathbf{C G}^{\mathbf{1}}$} & \multirow{2}{*}{ Pasture $^{2}$} & \multicolumn{5}{c}{ Crude glycerin level (\%) } \\
\cline { 5 - 8 } & & & $\mathbf{0 . 0 0}$ & $\mathbf{4 . 0 0}$ & $\mathbf{8 . 0 0}$ & $\mathbf{1 2 . 0 0}$ & $\mathbf{1 6 . 0 0}$ \\
\hline Dry matter (\%) & 90.00 & 59.82 & 87.02 & 82.63 & 78.11 & 74.04 & 69.50 \\
Organic matter (\% DM) & 93.00 & 92.26 & 95.29 & 96.03 & 94.64 & 94.22 & 92.15 \\
Crude protein (\% DM) & - & 6.17 & 20.91 & 21.81 & 22.64 & 22.77 & 23.17 \\
Ether extract (\% DM) & 36.70 & 1.36 & 2.68 & 6.61 & 8.94 & 10.68 & 12.60 \\
NDFap (\% DM) & - & 74.45 & 7.96 & 9.27 & 8.24 & 8.53 & 5.52 \\
ADF (\% DM) & - & 46.25 & - & - & - & - & - \\
NFC (\% DM) & - & 10.28 & 56.08 & 55.87 & 50.01 & 45.80 & 51.58 \\
Hemicellulose (\% DM) & - & 34.96 & - & - & - & - & - \\
Cellulose (\% DM) & - & 8.73 & - & - & - & - & - \\
Lignin (\% DM) & - & 5.70 & - & - & - & - & - \\
iNDF (\% DM) & - & 29.15 & 2.71 & 2.97 & 3.30 & 2.53 & 2.71 \\
Methanol & 5.73 & - & - & - & - & - & - \\
Glycerol & 51.84 & - & - & - & - & - & - \\
\hline
\end{tabular}

${ }^{1}$ Crude glycerin; ${ }^{2}$ Hand-plucked samples (simulated grazing).

Because of the presence of urea in the diets, the non-fibrous carbohydrates (NFC) were calculated as proposed by Hall (2000), represented by Eq. 3:

$$
\text { Eq. } 3=\mathrm{NFC}=\{100-[(\% \mathrm{CP}-\% \mathrm{CP} \text { urea }+\% \text { urea })+\% \text { NDFap }+\% \text { EE }+\% \mathrm{MM}]\}
$$

where $\mathrm{NFC}=$ non-fibrous carbohydrates; $\% \mathrm{CP}=$ percentage of crude protein; $\% \mathrm{CP}$ urea $=$ percentage of crude protein from urea; \%urea $=$ percentage of urea; $\%$ NDFap $=$ percentage of neutral detergent fiber (corrected for ash and protein); $\% \mathrm{EE}=$ percentage of ether extract; and $\% \mathrm{MM}=$ percentage of mineral matter (Table 3 ).

The total digestible nutrients (TDN) contents were estimated according to Weiss (1999), by the following equation:

$\mathrm{TDN}(\%)=\mathrm{DCP}+\mathrm{DNDFap}+\mathrm{DNFC}+2.25$ DEE,

where DCP = digestible crude protein; DNDFap $=$ digestible neutral detergent fiber corrected for ash and protein; DNFC = digestible non-fibrous carbohydrates; and DEE = digestible ether extract.

To measure the feeding behavior of the animals, 20 trained observers were selected to visually observe the following behavioral variables: grazing time, rumination time, time at the trough, and idle time of the animals, adopting a 5-min interval between observations, with data recorded in specific tables (SILVA et al., 2006).

During the collection period, animals remained on the grazing system in each paddock, keeping the same stocking rate of 12 animals per treatment. Of these, six were selected according to randomization criteria to make up the group of animals that would be subjected to behavioral analyses.

Animals subjected to the feeding behavior analyses were marked with red paint using a baton sold in agriculture shops (typically used in contests and animal judging in livestock fairs). Animals were marked on the day before analysis of the behavioral variables.

Two observers were allocated to each paddock to be in charge of analyzing the behavioral variables of six animals for a period of $2 \mathrm{~h}$, after which they 
switched with other observers who had been resting at the farm. In this regard, two collections were made to be used for the analysis of the feeding behavior of animals, which took place in the middle of each experimental period, both lasting $24 \mathrm{~h}$.

The average number of rumination chews per cud and of the time spent to ruminate each cud in the day and nighttime periods was obtained by visual observation and using digital stopwatches.

The total chewing time was determined as the sum of the grazing and rumination times. The discretization of time series was performed directly on the data collection spreadsheets, by counting the discrete periods spent grazing, ruminating, idle, and at the trough (SILVA et al., 2006).

Blood was collected by jugular vein puncture in the beginning of the first and second experimental periods. Approximately $4 \mathrm{~h}$ after the morning feed was supplied, the blood was drawn from six heifers from each group referring to a given treatment. Next, blood samples were transferred to the laboratory, centrifuged at 5,000 rpm for $15 \mathrm{~min}$, and the plasma was stored in 5-mL microcentrifuge tubes and kept frozen at $-15^{\circ} \mathrm{C}$ until analyses.

A spot urine sample was collected during spontaneous urination, in the middle of the experiment, approximately $4 \mathrm{~h}$ after the feed was supplied. Urine samples were collected from six heifers of each group referring to a given treatment. Samples were filtered through gauze, and a 10$\mathrm{mL}$ aliquot was separated and diluted with $40 \mathrm{~mL}$ sulfuric acid $(0.036 \mathrm{~N})$, used for quantifying the urea, nitrogen, creatinine, allantoin, and uric acid concentrations in the urine. Samples were packed in an universal collector and kept frozen at $-15{ }^{\circ} \mathrm{C}$.

Plasma and urine concentrations of creatinine, uric acid, and urea were estimated using commercial kits. Urea values were converted to urea nitrogen by multiplying the obtained values by 0.4667 . Allantoin and uric acid in the urine were estimated by colorimetric methods, as specified by Chen and Gomes (1992), and the total nitrogen content was estimated by the Kjeldahl method (SILVA; QUEIROZ, 2002).

The nitrogen balance $\left(\mathrm{N}\right.$ retained, $\mathrm{g} \mathrm{day}^{-1}$ ) was calculated as follows: $\mathrm{N}$ retained $=\mathrm{N}$ intake $(\mathrm{g})-\mathrm{N}$ in feces $(\mathrm{g})$ - $\mathrm{N}$ in urine $(\mathrm{g})$.

Creatinine excretion (mg $\mathrm{kg} \mathrm{LW}$ ), utilized to estimate the urinary volume from spot samples, was obtained for each animal, according to Eq. 5, described by (CHIZZOTTI et al, 2006).

Eq. $5=\mathrm{EC}=(32.27-0.01093) \times(\mathrm{LW})$,

where $\mathrm{EC}=$ daily excretion of creatinine $(\mathrm{mg} \mathrm{kg}$ $\left.\mathrm{LW}^{-1}\right)$ and $\mathrm{LW}=$ live weight $(\mathrm{kg})$.

The urinary volume was estimated as the ratio between the excretion of creatinine $(\mathrm{mg} \mathrm{kg}$ $\mathrm{LW}^{-1} \mathrm{day}^{-1}$ ), obtained in Eq. 5, and the average concentration in urine samples $\left(\mathrm{mg} \mathrm{dL}^{-1}\right)$, multiplying the result by the live weight of the animal.

Excretion of total purines (TP) was estimated as the sum of the amounts of allantoin and uric acid excreted in urine and the amount of microbial purines absorbed $\left(\mathrm{mmol} \mathrm{day}^{-1}\right)$, by the excretion of total purines $\left(\right.$ mmolday $\left.^{-1}\right)$, as shown in Eq. 6:

$$
\text { Eq. } 6=\text { AP }=\frac{\text { TP }-0.385 \times \text { LW0.75) }}{0.85},
$$

where AP $=$ absorbed purines $\left(\right.$ mmolday $\left.^{-1}\right)$; TP $=$ total purines $\left(\right.$ mmolday $\left.^{-1}\right) ; 0.85=$ recovery of absorbed purines as purine derivatives in urine; and $0.385=$ endogenous excretion of purine derivatives in urine ( $\mathrm{mmol})$ per unit of metabolic weight.

The intestinal flow of microbial nitrogen ( $\mathrm{g} \mathrm{MN}$ day $^{-1}$ ) was estimated from the amount of absorbed purines (mmolday $\left.{ }^{-1}\right)$, according to Eq. 7, described by Chen and Gomes (1992).

$$
\text { Eq. } 7=\operatorname{MN}\left(\frac{\mathrm{g}}{\text { day }}\right)=\frac{(70 \times \mathrm{AP})}{0.83 \times 0.116 \times 1000},
$$

assuming the value of 70 for the nitrogen content in the purines $\left(\mathrm{mg} \mathrm{mmol}^{-1}\right) ; 0.83$ for the intestinal digestibility of the microbial purines; and 0.116 for the purine-N: total-bacterial-N ratio. 
All statistical analyses were evaluated by analyses of variance (ANOVA) and regression, using the System for Statistical and Genetic Analyses (SAEG, 2000). The statistical models were chosen according to the significance of the coefficients of regression, using the $\mathrm{t}$ test at 5\% probability level, the coefficient of determination $\left(\mathrm{r}^{2}\right)$, and the studied phenomena.

\section{Results and Discussion}

Grazing and rumination times (Table 4) decreased linearly $(\mathrm{P}<0.05)$ by 7.44 and $3.91 \mathrm{~min}$, respectively, with every percent of crude glycerin included in the diet. The effect observed on grazing time can be explained by the greater heat increment provided by inclusion of crude glycerin in the diet, because the energy content (carbohydrates and lipids) of the diet is transformed into propionate, which is the first to signal the end of a meal, through the greater flow towards the liver. As a result, energy production (ATP) is increased through its use in gluconeogenesis, which signals the animal satiety (FARIAS et al., 2012). Thus, in larger quantities, crude glycerin benefits the intake-regulation mechanism of animals grazing on Brachiaria brizantha pastures during the dry season.

Table 4. Behavioral activities of Nellore heifers supplemented with different levels of crude glycerin.

\begin{tabular}{lccccccc}
\hline \multirow{2}{*}{ Activity (min) } & \multicolumn{9}{c}{ Crude glycerin level (\%) } & \multirow{2}{*}{ CV (\%) } & \multirow{2}{*}{$\mathbf{P}^{\mathbf{2}}$} \\
\cline { 2 - 7 } & $\mathbf{0 . 0 0}$ & $\mathbf{4 . 0 0}$ & $\mathbf{8 . 0 0}$ & $\mathbf{1 2 . 0 0}$ & $\mathbf{1 6 . 0 0}$ & & \\
\hline Grazing $^{3}$ & 496.25 & 485.83 & 450.83 & 415.83 & 382.50 & 10.69 & 0.001 \\
Rumination $^{4}$ & 455.42 & 366.25 & 331.66 & 419.17 & 350.83 & 15.66 & 0.001 \\
Idleness $^{5}$ & 448.75 & 528.75 & 600.00 & 551.67 & 653.33 & 11.16 & 0.001 \\
Trough $^{6}$ & 39.16 & 57.50 & 57.50 & 53.33 & 52.50 & 28.15 & 0.020 \\
\hline
\end{tabular}

${ }^{1}$ Coefficient of variation; ${ }^{2}$ Probability of error; ${ }^{3} \mathrm{Y}=505.75-7.4375 \mathrm{x} . \mathrm{r}^{2}=0.98 ;{ }^{4} \mathrm{Y}=415.92-3.9065 \mathrm{x} . \mathrm{R}^{2}=0.23 ;{ }^{5} \mathrm{Y}=470.08+$ $10.802 \mathrm{x} . \mathrm{r}^{2}=0.79 ;{ }^{6} \mathrm{Y}=41.423+3.5992 \mathrm{x}-0.1898 \mathrm{x} 2 . \mathrm{R}^{2}=0.79$.

The effect observed on rumination time, in turn, is explained by the lower NDFap content of the diet with the inclusion of crude glycerin in the concentrate, since it is devoid of fiber in its chemical composition. Thus, as this ingredient was added to the diet, rumination time was reduced, and it is known that the presence and quantity of fiber in the diet is a key factor to trigger the rumination activity. Agreeing with these results, Pereira et al. (2007) observed that the time spent feeding and ruminating decreases proportionally to the reduction of NDF in the diet; as a consequence, the time spent idle was increased.

Crude glycerin inclusion in the heifers diet caused a linear increase $(\mathrm{P}<0.05)$ in idle time, which increased by 10.80 with every percent of crude glycerin added. This response can be explained by the results observed for the grazing and rumination activities, with decreased idle time.

The time spent at the trough responded quadratically $(\mathrm{P}<0.05)$, with maxima of $58.07 \mathrm{~min}$ estimated at the level of $9.48 \%$ of inclusion of crude glycerin in the diet, which may be related to the homogenization of crude glycerin with other mesh ingredients in the diet up to this level. As the levels of inclusion in the diet were increased, DM intake decreased, and this effect may be related to the excess crude glycerin in relation to the other ingredients of the diet.

The total DM intake (Table 5) decreased linearly $(\mathrm{P}<0.05)$ by $0.097 \mathrm{~kg}$ day $^{-1}$. Likewise, NDFap intake had a decreasing linear response $(\mathrm{P}<0.05)$, in 
which crude glycerin inclusion caused it to drop by $0.060 \mathrm{~kg} \mathrm{day}^{-1}$ animal $^{-1}$. This response was likely due to the high levels of crude glycerin added to the diet, which might have brought about an inhibitory effect on DM and NDFap intake as a result of the ether extract content in crude glycerin.

Table 5. Nutrient intake and feed and rumination efficiencies of Nellore heifers supplemented with different levels of crude glycerin.

\begin{tabular}{|c|c|c|c|c|c|c|c|}
\hline \multirow{2}{*}{ Intake } & \multicolumn{4}{|c|}{ Crude glycerin level (\%) } & \multirow[b]{2}{*}{16.00} & \multirow{2}{*}{$\mathrm{CV}(\%)^{1}$} & \multirow{2}{*}{$\mathbf{P}^{2}$} \\
\hline & 0.00 & 4.00 & 8.00 & 12.00 & & & \\
\hline \multicolumn{8}{|l|}{ Feed $\left(\mathrm{kg} \mathrm{day}^{-1}\right)$} \\
\hline DM intake $(\mathrm{kg})^{3}$ & 6.01 & 5.36 & 5.41 & 4.92 & 4.30 & 6.88 & 0.001 \\
\hline NDFap intake $(\mathrm{kg})^{4}$ & 3.15 & 2.76 & 2.79 & 2.51 & 2.06 & 6.53 & 0.001 \\
\hline CP intake $(\mathrm{kg})^{5}$ & 0.89 & 0.75 & 0.79 & 0.78 & 0.66 & 10.88 & 0.001 \\
\hline TDN intake $(\mathrm{kg})^{6}$ & 3.29 & 3.06 & 3.10 & 2.90 & 2.39 & 10.25 & 0.001 \\
\hline \multicolumn{8}{|l|}{ Efficiency } \\
\hline Pasture DM intake $\mathrm{h}^{-1}(\mathrm{~kg})^{7}$ & 0.95 & 0.66 & 0.73 & 0.60 & 0.63 & 10.17 & 0.001 \\
\hline Pasture NDFap intake $\mathrm{h}^{-1}(\mathrm{~kg})^{8}$ & 0.49 & 0.34 & 0.38 & 0.31 & 0.30 & 10.14 & 0.001 \\
\hline Dietary TDN intake $\mathrm{h}^{-1}(\mathrm{~kg})^{9}$ & 0.52 & 0.38 & 0.42 & 0.35 & 0.35 & 10.15 & 0.001 \\
\hline Rumination, pasture $\mathrm{DM} \mathrm{h}^{-1}(\mathrm{~kg})^{10}$ & 1.09 & 0.89 & 1.00 & 0.65 & 0.62 & 19.62 & 0.001 \\
\hline Rumination, pasture $\mathrm{NDF} \mathrm{h}^{-1}(\mathrm{~kg})^{11}$ & 0.57 & 0.46 & 0.51 & 0.33 & 0.29 & 19.92 & 0.001 \\
\hline
\end{tabular}

${ }^{1}$ Coefficient of variation; ${ }^{2}$ Probability of error; ${ }^{3} \mathrm{Y}=5.976-0.0973 \mathrm{x} . \mathrm{r}^{2}=0.91 ;{ }^{4}$ Neutral detergent fiber corrected for ash and protein $;{ }^{5} \mathrm{Y}=3.14-0.0608 \mathrm{x} . \mathrm{r}^{2}=0.91 ;{ }^{6} \mathrm{Y}=3.34-0.049 \mathrm{x} . \mathrm{r}^{2}=0.82 ;{ }^{7} \mathrm{Y}=0.854-0.0175 \mathrm{x} . \mathrm{r}^{2}=0.64 ;{ }^{8} \mathrm{Y}=0.446-0.0103 \mathrm{x} . \mathrm{r}^{2}=$ $0.71 ;{ }^{9} \mathrm{Y}=0.478-0.0093 \mathrm{x} . \mathrm{r}^{2}=0.68 ;{ }^{10} \mathrm{Y}=1.086-0.0295 \mathrm{x} . \mathrm{r}^{2}=0.81 ;{ }^{11} \mathrm{Y}=0.57-0.0173 \mathrm{x} . \mathrm{r}^{2}=0.84$.

Crude protein $(\mathrm{CP})$ intake decreased linearly $(\mathrm{P}<0.05)$ by $0.010 \mathrm{~kg}$ day $^{-1}$ with every percent of inclusion of crude glycerin in the diet. This response was due to the reduction of mesh concentrate in the composition of the diets for the treatments with higher levels of crude glycerin, which does not have $\mathrm{CP}$ in its composition, thereby providing a decrease in intake by animals.

Total digestible nutrients (TDN) intake decreased linearly $(\mathrm{P}<0.05)$ by 0.049 kg.day ${ }^{-1}$ with every percent of crude glycerin included in the diet. The decreasing linear effect for the intake of the dietary nutrients was caused by the lower DM intake by the heifers, through the use of the crude glycerin in their feeding.

Feed efficiency in DM, NDFap, and TDN showed a linear decrease $(\mathrm{P}<0.05)$ of $0.02 \mathrm{~kg} \mathrm{DM} \mathrm{h}^{-1}, 0.01$ $\mathrm{kg} \mathrm{NDFap} \mathrm{h}^{-1}$, and $0.1 \mathrm{~kg} \mathrm{TDN} \mathrm{h}{ }^{-1}$, respectively, with every percent of crude glycerin included in the diet. The same effect was observed for rumination efficiency in DM and NDFap, which decreased linearly $(\mathrm{P}<0.05)$ by $0.03 \mathrm{~kg} \mathrm{DM} \mathrm{h}^{-1}$ and $0.02 \mathrm{~kg}$ NDFap $h^{-1}$, respectively.

This observed decreasing response was as a result of the decreased DM and NDFap intake as crude glycerin was added to the diet, even though a discrepancy was observed in the times spent feeding and ruminating. These findings corroborate Costa et al. (2011), who detected an increase in feed and rumination efficiency with an increase in DM and NDF intake.

Total chewing time (Table 6) decreased linearly $(\mathrm{P}<0.05)$, from 990.83 to $785.83 \mathrm{~min}$, with inclusion of crude glycerin in the diets. This response follows the trend shown by the times spent feeding and ruminating, which also decreased linearly, although the time spent at the trough had a quadratic effect. 
Table 6. Behavioral activities of Nellore heifers supplemented with different levels of crude glycerin.

\begin{tabular}{|c|c|c|c|c|c|c|c|}
\hline \multirow{2}{*}{ Behavioral activity } & \multicolumn{5}{|c|}{ Crude glycerin level (\%) } & \multirow{2}{*}{ CV $(\%)^{1}$} & \multirow{2}{*}{$\mathbf{P}^{2}$} \\
\hline & $\mathbf{0 . 0 0}$ & 4.00 & 8.00 & 12.00 & 16.00 & & \\
\hline Total chewing time $(\mathrm{min})^{3}$ & 990.83 & 909.58 & 839.99 & 888.33 & 785.83 & 7.06 & 0.001 \\
\hline Number of cuds ruminated per day ${ }^{4}$ & 507.62 & 401.66 & 352.15 & 467.99 & 369.69 & 14.55 & 0.001 \\
\hline Time spent per ruminated cud $(\mathrm{s})^{5}$ & 53.83 & 54.71 & 56.51 & 53.74 & 56.94 & 14.16 & 0.001 \\
\hline Number of chews per ruminated cud ${ }^{6}$ & 53.46 & 52.98 & 56.64 & 57.90 & 55.27 & 14.14 & 0.001 \\
\hline
\end{tabular}

${ }^{1}$ Coefficient of variation; ${ }^{2}$ Probability of error; ${ }^{3} \mathrm{Y}=969.16-10.781 \mathrm{x} . \mathrm{r}^{2}=0.79 ;{ }^{4} \mathrm{Y}=487.54-18.143 \mathrm{x}+0.8066 \mathrm{x}^{2} . \mathrm{R}^{2}=0.38 ;{ }^{5} \mathrm{Y}=$ $54.096+0.1313 \mathrm{x} \cdot \mathrm{r}^{2}=0.31 ;{ }^{6} \mathrm{Y}=52.585+0.6921 \mathrm{x}-0.0299 \mathrm{x}^{2} \cdot \mathrm{R}^{2}=0.61$.

The number of cuds ruminated per day showed a quadratic effect $(\mathrm{P}<0.05)$, with a minimum of 385.97 cuds obtained at $11.25 \%$ inclusion of glycerin. This was an expected result, because the same effect was found for the time spent on rumination, which is a natural process performed by cattle that is important to improve the use of the feed, mainly the fiber. Thus, crude glycerin showed to provide a decrease in DM and NDF intake, and consequently the number of cuds ruminated was compromised.
The time spent per ruminated cud increased linearly $(\mathrm{P}<0.05)$ by $0.13 \mathrm{~s}$ with every percent of crude glycerin added to the diet. The number of chews per ruminated cud, however, had a quadratic response $(\mathrm{P}<0.05)$, with maximum value of 56.58 chews for the level of $11.57 \%$ of crude glycerin added to the diet. This result is related to the rumination time.

There was no effect $(\mathrm{P}>0.05)$ of glycerin inclusion on the number of grazing and rumination periods (Table 7), which averaged 10.01 and 10.00 periods, respectively.

Table 7.Frequencies and duration of behavioral activities of Nellore heifers supplemented with different levels of crude glycerin.

\begin{tabular}{|c|c|c|c|c|c|c|c|}
\hline \multirow{2}{*}{ Behavioral activity } & \multicolumn{5}{|c|}{ Crude glycerin level (\%) } & \multirow{2}{*}{$\mathrm{CV}(\%)^{1}$} & \multirow{2}{*}{$\mathbf{P}^{2}$} \\
\hline & $\mathbf{0 . 0 0}$ & 4.00 & 8.00 & 12.00 & 16.00 & & \\
\hline Number of grazing periods ${ }^{3}$ & 9.91 & 9.75 & 10.21 & 9.91 & 10.25 & 21.47 & 0.674 \\
\hline Number of rumination periods ${ }^{4}$ & 10.17 & 10.33 & 9.42 & 9.83 & 10.25 & 18.93 & 0.906 \\
\hline Number of idle periods ${ }^{5}$ & 13.75 & 14.08 & 16.25 & 15.17 & 17.17 & 18.69 & 0.024 \\
\hline Number of periods at the trough ${ }^{6}$ & 2.17 & 1.83 & 2.08 & 1.42 & 1.42 & 33.88 & 0.005 \\
\hline Grazing time per period $(\min )^{7}$ & 50.07 & 49.83 & 44.15 & 41.96 & 37.32 & 22.36 & 0.001 \\
\hline Rumination time per period $(\mathrm{min})^{8}$ & 44.78 & 35.45 & 35.21 & 42.64 & 34.23 & 15.94 & 0.001 \\
\hline Idle time per period $(\mathrm{min})^{9}$ & 32.64 & 37.55 & 36.92 & 36.36 & 38.05 & 22.97 & 0.361 \\
\hline Time at trough per period $(\min )^{10}$ & 18.05 & 31.42 & 27.64 & 37.56 & 36.97 & 32.93 & 0.001 \\
\hline
\end{tabular}

${ }^{1}$ Coefficient of variation; ${ }^{2}$ Probability of error; ${ }^{3} \mathrm{Y}=10.01 ;{ }^{4} \mathrm{Y}=10.00 ;{ }^{5} \mathrm{Y}=13.698+0.1983 \mathrm{x} . \mathrm{r}^{2}=0.76 ;{ }^{6} \mathrm{Y}=2.166-0.0478 \mathrm{x} . \mathrm{r}^{2}=$ $0.72 ;{ }^{7} \mathrm{Y}=51.34-0.8343 \mathrm{x} . \mathrm{r}^{2}=0.95 ;{ }^{8} \mathrm{Y}=41.244-0.3477 \mathrm{x} . \mathrm{r}^{2}=0.21 ;{ }^{9} \mathrm{Y}=36.30 ;{ }^{10} \mathrm{Y}=21.532+1.0995 \mathrm{x} . \mathrm{r}^{2}=0.80$.

Nevertheless, DM and NDF intake increased linearly with inclusion of crude glycerin. The time per grazing and rumination periods was reduced to
0.83 and $0.35 \mathrm{~min}$, respectively, for every percent of crude glycerin included in the diet. A similar response was found by Almeida (2011), working 
with the levels of $0.00,3.33,6.66$, and $9.99 \%$ crude glycerin in diets for heifers on a grazing system, in which the author observed an average number of grazing periods of 15.1 and a 0.68 min decrease with every percent of inclusion of crude glycerin in the diet.

The number of idle periods increased linearly $(\mathrm{P}<0.05)$ by 0.20 periods with each percent of inclusion of crude glycerin in the diet. The idle time per period, however, did not show significant effects, averaging $36.30 \mathrm{~min}$. This result reflects the response observed for idle time, in which the inclusion of crude glycerin in the diet provided a longer time.

The number of periods at the trough decreased linearly $(\mathrm{P}<0.05)$, with a reduction of 0.05 periodsfor every percent of glycerin inclusion. The animals visited the trough fewer times, but remained there longer as crude glycerin was included in the diet. The time spent at the trough showed an increasing effect $(\mathrm{P}<0.05)$, increasing by $1.10 \mathrm{~min}$ with the inclusion of crude glycerin in the diet. This effect can be explained by the acceptability and difficulty seizing the glycerin by the animals, with elevated levels of crude glycerin in the diet making the supplement less palatable or leading to greater difficulty to seize it; as a consequence, heifers remained at the trough for a longer time with the inclusion of glycerin in the diet.

The urinary volume showed a decreasing linear effect $(\mathrm{P}<0.05)$, with a $0.22 \mathrm{~L}$ reduction observed with every percent unit of crude glycerin added to the diet (Table 8). This effect may be related to the lower DM intake, which then led to a reduction in water intake by the animals during the day, culminating in a lower urinary excretion volume.

Table 8. Urinary volume, excretion of purine derivatives, microbial protein production, and microbial efficiency of Nellore heifers supplemented with different levels of crude glycerin.

\begin{tabular}{|c|c|c|c|c|c|c|c|}
\hline \multirow{2}{*}{ Item } & \multicolumn{5}{|c|}{ Crude glycerin level (\%) } & \multirow{2}{*}{$\mathrm{CV}(\%)^{1}$} & \multirow{2}{*}{$\mathbf{P}^{2}$} \\
\hline & $\mathbf{0 . 0 0}$ & 4.00 & 8.00 & 12.00 & 16.00 & & \\
\hline Urinary volume $\left(\mathrm{L} \mathrm{day}^{-1}\right)^{3}$ & 13.22 & 12.79 & 11.76 & 10.00 & 10.26 & 21.69 & 0.006 \\
\hline \multicolumn{8}{|l|}{ Urinary excretions $\left(\right.$ mmolday $\left.^{-1}\right)$} \\
\hline Allantoin 4 & 84.43 & 71.84 & 69.48 & 75.54 & 79.11 & 38.27 & 0.893 \\
\hline Uric $\operatorname{acid}^{5}$ & 16.55 & 13.38 & 14.39 & 8.36 & 11.31 & 46.19 & 0.016 \\
\hline Total purines $^{6}$ & 100.98 & 85.22 & 83.87 & 83.90 & 90.41 & 32.49 & 0.722 \\
\hline Absorbed microbial purines ${ }^{7}$ & 87.30 & 69.13 & 67.00 & 67.04 & 74.87 & 38.25 & 0.721 \\
\hline \multicolumn{8}{|l|}{ In \% total purines } \\
\hline Allantoin $^{8}$ & 81.80 & 77.64 & 83.12 & 89.51 & 87.09 & 10.64 & 0.018 \\
\hline 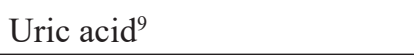 & 18.20 & 22.36 & 16.88 & 10.49 & 12.91 & 55.17 & 0.018 \\
\hline \multicolumn{8}{|c|}{ Syntheses of $\mathrm{N}$ and microbial protein $\left(\mathrm{g} \mathrm{day}^{-1}\right)$} \\
\hline Microbial $N^{10}$ & 63.47 & 50.26 & 48.71 & 48.74 & 54.43 & 38.25 & 0.721 \\
\hline Microbial $\mathrm{CP}^{11}$ & 396.70 & 314.14 & 304.46 & 304.65 & 340.21 & 38.25 & 0.721 \\
\hline \multicolumn{8}{|l|}{ Microbial efficiency } \\
\hline $\mathrm{g} \mathrm{CP} \mathrm{kg} \mathrm{TDN}^{-1} 12$ & 120.61 & 102.72 & 98.00 & 105.03 & 142.31 & 37.32 & 0.122 \\
\hline
\end{tabular}

${ }^{1}$ Coefficient of variation; ${ }^{2}$ Probability of error; ${ }^{3} \mathrm{Y}=13.348-0.2178 \mathrm{x} . \mathrm{r}^{2}=0.90 ;{ }^{4} \mathrm{Y}=76.08 ;{ }^{5} \mathrm{Y}=15.898-0.3875 \mathrm{x} . \mathrm{r}^{2}=0.62 ;{ }^{6} \mathrm{Y}$ $=88.88 ;{ }^{7} \mathrm{Y}=73.07 ;{ }^{8} \mathrm{Y}=79.342+0.5613 \mathrm{x} . \mathrm{r}^{2}=0.59 ;{ }^{9} \mathrm{Y}=20.658-0.5612 \mathrm{x} . \mathrm{r}^{2}=0.59 ;{ }^{10} \mathrm{Y}=53.12 ;{ }^{11} \mathrm{Y}=332.03 ;{ }^{12} \mathrm{Y}=113.73$ 
No significant effects $(\mathrm{P}>0.05)$ were observed for the urinary excretion of allantoin, total purines, and absorbed microbial proteins, which averaged 76.08, 88.88, and $73.07 \mathrm{mmol} \mathrm{day}^{-1}$, respectively. Because the excretions of allantoin, total purines, and absorbed microbial purines are related to the intake of crude protein from the diet, a decreasing linear effect was expected, given the lower crude protein intake of the animals resulting from the inclusion of crude glycerin, which provided a decrease in the intakes of DM and respective diet nutrients.

However, the excretion of uric acid decreased linearly $(\mathrm{P}<0.05)$, with every percent unit of crude glycerin causing it to decrease by 0.39 mmolday $^{-1}$. This was an expected result, given the reduction of crude protein intake caused by the inclusion of glycerin, as mentioned previously.

Allantoin excretion as a percentage of total protein showed an increasing response $(\mathrm{P}<0.05)$, increasing by $0.56 \%$ with every percent unit of crude glycerin included in the diet. The opposite effect $(\mathrm{P}<0.05)$ was observed for uric acid excretion as a percentage of the total protein, which decreased by $0.56 \%$ with every percent unit of crude glycerin. This result was expected, since the excretion of uric acid showed a decreasing effect and the excretion of total purines was similar.

The microbial nitrogen and microbial crude protein syntheses did not show a significant response $(\mathrm{P}>0.05)$, averaging 53.12 and $332.03 \mathrm{~g} \mathrm{day}^{-1}$. This response can be explained by the digestibility of $\mathrm{CP}$ being $60 \%$. The microbial protein synthesis depends largely on the availability of carbohydrates and nitrogen in the rumen, such that microbial growth is maximized by the synchronism between the availability of fermentable energy and the rumendegradable nitrogen. Therefore, it is estimated that all tested diets provided similar efficiency and growth to the rumen microorganisms, irrespective of the reduction in DM intake, which possibly occurred due to the satiety mechanism caused by the energy content of the diet.

No significant response was observed for grams of microbial protein per kilogram of total digestible nutrients ( $\mathrm{g} \mathrm{CP} \mathrm{kg} \mathrm{TDN}^{-1}$ ), either, which averaged $113.73 \mathrm{~g} \mathrm{CP} \mathrm{kg} \mathrm{TDN}{ }^{-1}$. This result followed the same effect as CP digestibility, which was not significantly affected, averaging $60 \%$.

Microbial production was lower than the $130 \mathrm{~g}$ $\mathrm{CP} \mathrm{kg} \mathrm{TDN}^{-1}$ reported by NRC (1996) and120 $\mathrm{g}$ $130 \mathrm{~g} \mathrm{CP} \mathrm{kg} \mathrm{TDN}^{-1}$ by Leal et al. (2007).

Nitrogen intake and nitrogen excreted in feces decreased linearly $(\mathrm{P}<0.05)$ by 1.74 and $1.22 \mathrm{~g}$ day $^{-1}$, respectively, with every percent unit of glycerin added to the diet (Table 9). This effect can be explained by the lower DM intake of the animals as glycerin was included in the diet.

The nitrogen excreted in the feces consists of the nitrogen consumed from the diet, the desquamation of cells from the gastrointestinal tract, the proteins that move into the duodenum, and microbial proteins. High-protein diets usually provide a greater nitrogen excretion in the feces.

Results for digested nitrogen per day, digested nitrogen as a percentage of nitrogen intake, nitrogen in urine per day, nitrogen retained per day, nitrogen retained as a percentage of nitrogen intake, and nitrogen retained as a percentage of the digested nitrogen did not differ ( $\mathrm{P}>0.05)$, averaging $74.69 \mathrm{~g}$ day $^{-1}, 60.00 \%, 19.10 \mathrm{~g} \mathrm{day}^{-1}, 55.60 \mathrm{~g} \mathrm{day}^{-1}, 43.53 \%$, and $73.34 \%$ with inclusion of crude glycerin in the diet. These effects can be explained by the fact that the diet was formulated to be isoproteic, and thus elicited a similar response from the balance of nitrogen compounds.

Urine urea nitrogen decreased linearly $(\mathrm{P}<0.05)$ by $3.93 \mathrm{mg} \mathrm{dL}^{-1}$ with every percent unit of crude glycerin added to the diet. This result stemmed from the reduction of DM intake from the diet, which decreased with the inclusion of crude glycerin in the diets. 
Table 9. Balance of nitrogen compounds of Nellore heifers supplemented with different levels of crude glycerin.

\begin{tabular}{|c|c|c|c|c|c|c|c|}
\hline \multirow{2}{*}{ Balance of nitrogen compounds } & \multicolumn{5}{|c|}{ Crude glycerin level (\%) } & \multirow{2}{*}{ CV $(\%)^{1}$} & \multirow{2}{*}{$\mathbf{P}^{2}$} \\
\hline & 0.00 & 4.00 & 8.00 & 12.00 & 16.00 & & \\
\hline $\mathrm{N}$ intake $\left(\mathrm{g} \mathrm{day}^{-1}\right)^{3}$ & 142.88 & 119.64 & 126.93 & 125.41 & 105.27 & 10.88 & 0.001 \\
\hline $\mathrm{N}$ feces $\left(\mathrm{g} \mathrm{day}^{-1}\right)^{4}$ & 60.10 & 50.56 & 51.92 & 46.19 & 37.88 & 9.60 & 0.001 \\
\hline $\mathrm{N}$ digested $\left(\mathrm{g} \mathrm{day}^{-1}\right)^{5}$ & 82.79 & 69.08 & 75.00 & 79.22 & 67.38 & 17.74 & 0.243 \\
\hline $\mathrm{N}$ digested (\% of $\mathrm{N}$ intake) $)^{6}$ & 57.85 & 56.42 & 59.05 & 62.63 & 64.05 & 9.67 & 0.149 \\
\hline Urine $\mathrm{N}\left(\mathrm{g} \mathrm{day}^{-1}\right)^{7}$ & 26.25 & 20.77 & 19.07 & 16.46 & 12.93 & 54.48 & 0.272 \\
\hline $\mathrm{N}$ retained $\left(\mathrm{g} \mathrm{day}^{-1}\right)^{8}$ & 56.53 & 48.31 & 55.93 & 62.76 & 54.45 & 32.94 & 0.888 \\
\hline $\mathrm{N}$ retained $(\% \text { of } \mathrm{N} \text { intake })^{9}$ & 33.80 & 38.96 & 43.92 & 49.18 & 51.79 & 26.17 & 0.223 \\
\hline $\mathrm{N}$ retained $(\% \text { of } \mathrm{N} \text { digested })^{10}$ & 66.89 & 67.01 & 74.17 & 77.88 & 80.79 & 23.05 & 0.665 \\
\hline \multicolumn{8}{|l|}{ Concentrations (mg dL $\left.{ }^{-1}\right)$} \\
\hline Urine urea $\mathrm{N}^{11}$ & 322.00 & 285.07 & 293.68 & 270.17 & 250.81 & 13.15 & 0.001 \\
\hline Plasma urea $\mathrm{N}^{12}$ & 13.63 & 13.08 & 12.35 & 13.85 & 12.64 & 18.42 & 0.163 \\
\hline \multicolumn{8}{|l|}{ Excretions $\left(\right.$ g day $\left.^{-1}\right)$} \\
\hline Urine urea $\mathrm{N}^{13}$ & 41.27 & 36.03 & 34.48 & 27.22 & 25.68 & 20.50 & 0.001 \\
\hline Urine urea $^{14}$ & 19.23 & 16.79 & 16.07 & 12.68 & 11.97 & 20.50 & 0.001 \\
\hline
\end{tabular}

Plasma urea nitrogen did not show to be significantly affected $(\mathrm{P}>0.05)$ by inclusion of crude glycerin in the heifers diet, averaging 13.11 $\mathrm{mg} \mathrm{dL}^{-1}$. Blood urea concentrations have been used for monitoring the intake of dietary protein near the animal requirements, since excess protein consumption may affect the productive and reproductive performance of an animal, as stated by Carvalho et al. (2011), elevating its energy requirements or even increasing the feed cost.

The excretion of urea nitrogen and urea in the nitrogen decreased linearly $(\mathrm{P}<0.05)$ by 1.0 and 0.47 $\mathrm{g}$ day $^{-1}$, respectively, with every percent of crude glycerin added to the diet. These results are related to the lower DM intake and consequent lower CP intake from the total diet. Considering the plasma urea nitrogen concentration of $13.11 \mathrm{mg} \mathrm{dL}^{-1}$, we observed that inclusion of glycerin in the heifer diets led to a lower loss of these nitrogen compounds through urinary and fecal excretions, as a result of the CP digestibility not being compromised.

A similar response was described by Teixeira et al. (2007), who did not observe differences in plasma urea concentration, but found a linear effect on urinary excretion of urea, attributed to the increase in total nitrogen intake.

The urine excretion represents a high biological cost and deviation of energy for the maintenance of the body nitrogen concentrations at non-toxic levels to animals. The conversion of ammonia to urea costs the animal $12 \mathrm{kcal}$ per gram of nitrogen (VAN SOEST, 1994).

This study indicated that the dietary CP was directed to the body tissues and converted to muscle gain, even though weight gain was lower with inclusion of crude glycerin in the diet, which was an expected result, since CP intake decreased as the levels of crude glycerin in the nutrition of animals were elevated. 


\section{Conclusion}

Inclusion of crude glycerin as a by-product in diets for heifers on a grazing system during the dry season alters the feeding behavior and reduces the time and efficiency of feeding and rumination activity, but does not influence the microbial protein synthesis or retained nitrogen of these animals.

\section{Acknowledgments}

To Coordenação de Aperfeiçoamento de Pessoal de Nivel Superior - CAPES, for the fellowship grant.

To the Animal Science Graduate Program - PPZ/ UESB, for the support in the studies during the Master's Degree Program in Animal Science.

To Professor Doutor Fabiano Ferreira da Silva, for his guidance.

To Professor Rogério Pinto de Paula - Director of the Library Regina Celia Ferreira Silva (BIRCEFS) - President of the Council of Libraries of UESB, for the support in correcting this work.-

\section{References}

ALMEIDA, V. V. S. Glicerina bruta em suplementos para novilhas mestiças em pastagens. 2011. Tese (Doutorado em Zootecnia) - Universidade Federal de Viçosa, Viçosa, MG.

CARVALHO, G. G. P.; GARCIA, R.; PIRES, A. J. V.; DETMANN, E.; SILVA, R. R.; PEREIRA, M. L. A.; SANTO, A. B.; PEREIRA, T. C. J. Metabolismo de nitrogênio em novilhas alimentadas com dietas contendo cana-de-açúcar tratada com óxido de cálcio. Revista Brasileira de Zootecnia, Viçosa, MG, v. 40, n. 3, p. 622-629, 2011. Disponível em: <http://www. scielo.br/pdf/rbz/v40n3/22.pdf>. Acesso em: $10 \mathrm{fev}$. 2014.

CHEN, X. B.; GOMES, M. J. Estimation of microbial protein supply to sheep and cattle based on urinary excretion of purine derivatives: an overview of technical details. Bucksburnd: Rowett Research Institute/International Feed Research Unit, 1992. 21 p. (Occasional Publication). Available at: <http://www. macaulay.ac.uk/IFRU/pdf/chema.pdf $>$. Accessed at: 10 fev. 2014.
CHIZZOTTI, M. L.; VALADARES FILHO, S. C.; VALADARES, R. F. D.; CHIZZOTTI, F. H. M.; CAMPOS, J. M. S.; MARCONDES, M. I.; FONSECA, M. A. Consumo, digestibilidade e excreção de ureia e derivados de purinas em novilhas de diferentes pesos. Revista Brasileira de Zootecnia, Viçosa, MG, v. 35, n. 4, p. 1813-1821, 2006. Suplemento. Disponível em: <http:// dx.doi.org/10.1590/S1516-35982006000600032>. Acesso em: 10 fev. 2014.

COSTA, L. T.; SILVA, F. F.; VELOSO, C. M.; PIRES, A. J. V.; ROCHA NETO, A. L.; BONOMO, P.; MENDES, F. B. L.; OLIVEIRA, J. S.; AZEVÊDO, S. T.; SILVA, V. L. Comportamento ingestivo de vacas alimentadas com cana-de-açúcar e diferentes níveis de concentrado. Archivos de Zootecnia, Córdoba, v. 60, n. 230, p. 265273, 2011. Disponível em: <http://dx.doi.org/10.4321/ S0004-05922011000200011>. Acesso em: 10 fev. 2014.

FARIAS, M. S.; PRADO, I. N.; VALERO, M. V.; ZAWADZKI, F.; SILVA, R. R.; EIRAS, C. E.; RIVAROLI, D. C.; LIMA, B. S. Níveis de glicerina para novilhas suplementadas em pastagens: desempenho, ingestão, eficiência alimentar e digestibilidade. Semina: Ciências Agrárias, Londrina, v. 33, n. 3, p. 1177-1188, maio/jun. 2012. Disponível em: <http://dx.doi.org/10.5433/16790359.2012v33n3p1177>. Acesso em: 9 fev. 2014.

FERRARI, R. A.; OLIVEIRA, V. S.; SCABIO, A. Biodiesel de soja - taxa de conversão em ésteres etílicos, caracterização físico-química e consumo em gerador de energia. Química Nova, Vitória, v. 28, n. 1, p. 19-23, 2005.

HALL, M. B. Calculation of non-structural carbohydrate content of feeds that contain non-protein nitrogen. Gainesville: University of Florida, 2000. A-25 p. (Bulletin, 339).

LEAL, T. L.; VALADARES, R. F. D.; VALADARES FILHO, S. C.; LEÃO, M. I.; DETMANN, E.; BARBOSA, A. M.; CHIZZOTTI, M. L.; PAIXÃO, M. L. Variações diárias nas excreções de creatinina e derivados de purinas em novilhos. Revista Brasileira de Zootecnia, Viçosa, MG, v. 36, n. 4, p. 896-904, 2007. Disponível em: <http://www.scielo.br/pdf/rbz/ v36n4/20.pdf>. Acesso em: 10 fev. 2014.

MARTINS, S. C. S. G.; ROCHA JÚNIOR, V. R.; CALDEIRA, L. A.; BARROS, I. C.; SILVA, G. W. V.; COSTA, M. D.; PALMA, M. N. N.; SOUZA, A. S. Comportamento ingestivo de vacas mestiças alimentadas com diferentes volumosos. Revista Brasileira de Ciência Veterinária, Niterói, v. 19, n. 1, p. 13-20, 2012. Disponível em: <http://www.uff.br/rbcv/ ojs/index.php/rbcv/article/viewFile/10/pdf_4>. Acesso em: 12 fev. 2014. 
MERTENS, D. R. Gravimetric determination of amylase treated neutral detergent fiber in feeds with refluxing in beakers or crucibles: Collaborative study. Journal of AOAC International, Rockville, v. 85, n. 6, p. 12121240, 2002. Disponível em: <http://naldc.nal.usda.gov/ download/26403/PDF>. Acesso em: 12 fev. 2014.

NATIONAL RESEARCH COUNCIL - NRC. Nutrient requirements of beef cattle. $7^{\text {th }}$ ed. Washington, D. C.: Nat. Acad. Press, 1996. Available at: <http://www. uaex.edu/Other_Areas/publications/PDF/MP391.pdf $>$. Accessed at: 12 feb. 2014.

PEREIRA, J. C.; CUNHA, D. N. F. V.; CECON, P. R.; FARIA, E. S. Comportamento ingestivo e taxa de passagem de partículas em novilhas leiteiras de diferentes grupos genéticos submetidas a dietas com diferentes níveis de fibra. Revista Brasileira de Zootecnia, Viçosa, MG, v. 36, n. 6, p. 2134-2142, 2007. Suplemento. Disponível em: <http://dx.doi.org/10.1590/ S1516-35982007000900025>. Acesso em: 10 fev. 2014.

RODRIGUEZ, N. M.; SALIBA, E. O. S.; GUIMARÃES JUNIOR, R. Uso de indicadores para estimativa de consumo a pasto e digestibilidade. In: REUNIÃO ANUAL DA SOCIEDADE BRASILEIRA DE ZOOTECNIA, 43., 2006, João Pessoa. Anais... João Pessoa: Sociedade Brasileira de Zootecnia, 2006. p. 323-352.

$\mathrm{SCHIO}, \mathrm{A}$. R. Tipos de ureia em suplementos para novilhas Nelores em pastejo no periodo seco. 2012. Tese (Doutorado em Zootecnia) - Universidade Estadual do Sudoeste da Bahia, Itapetinga.

SILVA, D. J.; QUEIROZ, A. C. Análise de alimentos: métodos químicos e biológicos. 3. ed. Viçosa, MG: Editora UFV, 2002. 235 p.

SILVA, F. F.; SÁ, J. F.; SCHIO, A. R.; ÍTAVO, L. C. V.; SILVA, R. R.; MATEUS, R. G. Suplementação a pasto: disponibilidade e qualidade $\mathrm{x}$ níveis de suplementação $\mathrm{x}$ desempenho. Revista Brasileira de Zootecnia, Viçosa, MG, v. 38, n. 1, p. 371-389, 2009. Disponível em: $<$ http://www.scielo.br/pdf/rbz/v38nspe/v38nspea37. pdf $>$. Acesso em: 12 fev. 2014.

SILVA, R. R.; PRADO, I. N.; SILVA, F. F.; ALMEIDA, V. V. S.; SANTANA JÚNIOR, H. A.; QUEIROZ, A. C.; CARVALHO, G. G. P.; BARROSO, D. S. Comportamento ingestivo diurno de novilhos Nelore recebendo níveis crescentes de suplementação em pastejo de capimbraquiária. Revista Brasileira de Zootecnia, Viçosa, MG, v. 39, n. 9, p. 2073-2080, 2010. Disponível em: <http:// dx.doi.org/10.1590/S1516-35982010000900028>. Acesso em: 9 fev. 2014.
SILVA, R. R.; SILVA, F. F.; PRADO, I. N.; CARVALHO, G. G. P.; FRANCO, I. L.; MENDES, F. B. L.; CARDOSO, C. P.; PINHEIRO, A. A.; SOUZA, D. R. Metodologia para o estudo do comportamento de bezerros confinados na fase pós-aleitamento. Archivos Latino americanos de Producción Animal, Maracaibo, v. 14, n. 4, p. 135-138, 2006. Disponível em: <http:// www.alpa.org.ve/PDF/Arch\%2014-4/rsilva.pdf>. Acesso em: 12 fev. 2014.

SOUZA, A. N. M.; ROCHA, M. G.; POTTER, L.; ROSO, D.; GLIENKE, C. L.; OLIVEIRA NETO, R. A. Comportamento ingestivo de novilhas de corte em pastagem de gramíneas anuais de estação quente. Revista Brasileira de Zootecnia, Viçosa, MG, v. 40, n. 8, p. 1662-1670, 2011. Disponível em: <http://dx.doi. org/10.1590/S1516-35982011000800006>. Acesso em: 10 fev. 2014.

TEIXEIRA, R. M. A.; CAMPOS, J. M. S.; VALADARES FILHO, S. C.; VALADARES, R. F. D.; OLIVEIRA, A. S.; PINA, D. S. Balanço de compostos nitrogenados e produção de proteína microbiana em novilhas leiteiras alimentadas com casca de café em substituição à silagem de milho. Revista Brasileira de Zootecnia, Viçosa, MG, v. 36, n. 5, p. 1691-1698, 2007. Suplemento. Disponível em: <http://dx.doi. org/10.1590/S1516-35982007000700030>. Acesso em: 13 fev. 2014.

TITGEMEYER, E. C. Design and interpretation of nutrient digestion studies. Journal of Animal Science, Champaign, v. 75, n. 8, p. 2235-2247, 1997.

SISTEMA PARA ANÁLISES ESTATÍSTICAS E GENÉTICAS - SAEG. Sistema de análises estatísticas e genéticas - Versão 8.0.Viçosa, MG: UFV, 2000. 142 p.

VAN SOEST, P. J. Nutritional ecology of the ruminant. $2^{\text {th }}$ ed. Ithaca: Cornell University Press, 1994. 476 p.

WEISS, W. P. Energy prediction equations for ruminant feeds. In: CORNELL NUTRITION CONFERENCE FOR FEED MANUFACTURERS, 61., 1999, Ithaca. Proceedings... Ithaca: Cornell University, 1999. p. 176185. 
